\title{
POLITYKA SPOŁECZNA NIEPODLEGŁEJ RZECZYPOSPOLITEJ - BUDOWA I EWOLUCJA SYSTEMU
}

\section{Paweł Grata}

http://orcid.org/0000-0003-2358-3475

Uniwersytet Rzeszowski

\author{
ABSTRACT \\ SOCIAL POLICY OF THE INDEPENDENT POLISH REPUBLIC: \\ THE CONSTRUCTION AND THE EVOLUTION OF THE SYSTEM
}

Twenty years of independence turned out not to be long enough for the process of the construction of a coherent system of social policy to be finished. A complicated opening balance sheet, unfavourable economic and social structure of the state and, last but not least, a permanent lack of resources made it impossible to create a system which would satisfy existing needs. It remained in its construction phase and, though it was becoming more and more comprehensive, it was still extremely underfunded and flawed. This is confirmed by its limited coverage, which resulted from structural barriers. It was impossible to remedy this in the short interwar period, although the scale of problems and shortages was known. With time, social policy in Poland became a mature sphere of state activity, which is confirmed by the new objectives that currently lay before it, and by the regulatory and practical activities undertaken at the end of the 1930s.

Keywords: Second Polish Republic, social policy, employment policy, social security, public health care.

Słowa kluczowe: II Rzeczpospolita, polityka społeczna, polityka zatrudnienia, ubezpieczenia społeczne, publiczna służba zdrowia. 


\section{UWAGI WSTĘPNE}

Polityka społeczna, rozumiana jako sfera oddziaływania władz publicznych na kwestie społeczne, to jedna $\mathrm{z}$ wielu dziedzin życia publicznego, która wraz z odzyskaniem niepodległości miała stać się płaszczyzną aktywności suwerennego państwa polskiego. Nie była, rzecz jasna, dziedziną przed 1918 rokiem nieznaną, jednak powstawała w Europie wtedy, gdy Rzeczypospolitej na jej mapach nie było, co skutkowało nie tylko znaczącym zróżnicowaniem dostępnych na terenach polskich urządzeń i instytucji polityki społecznej, ale także sporym zapóźnieniem cywilizacyjnym, widocznym zwłaszcza na obszarach poddanych władzy Rosji. Te niekorzystne z punktu widzenia organizowania ładu społecznego cechy konstytuujące w sposób znaczący określały podstawowe założenia własnej polityki społecznej zarówno u progu niepodległości, jak też, co miało się dopiero okazać, w całym dwudziestoleciu międzywojennym.

Nie przez przypadek zatem w tytule niniejszego szkicu między budową systemu oraz jego ewolucją postawiony został spójnik wskazujący na równoległość obu opisywanych tymi pojęciami procesów. Budowa polskiej polityki społecznej rozpoczęła się wprawdzie już od pierwszych dni niepodległości, jednak okazała się ona na tyle rozciągnięta w czasie, że do wybuchu wojny nie została w pełni sfinalizowana. Najlepszym potwierdzeniem tak postawionej tezy może być fakt przyjmowania przez parlament jeszcze latem 1939 roku fundamentalnych ustaw o publicznej służbie zdrowia czy sądach ubezpieczeń społecznych, a także znacząca liczba wciąż nierozstrzygniętych regulacyjnie i instytucjonalnie kwestii szczegółowych.

Zasadniczym celem niniejszego opracowania jest przybliżenie obu wskazanych w tytule procesów, czyli trwającej de facto przez dwa dziesięciolecia budowy własnego systemu polityki społecznej, jak też zachodzącej w nim równolegle ewolucji. Ewolucji wypływającej z przewartościowywania priorytetów, jakie z czasem zachodziło, ale również ze zmieniających się uwarunkowań, zwłaszcza ekonomicznych, które szczególnie w latach trzydziestych odcisnęly wyraźne piętno na przeobrażeniach zachodzących w obrębie polityki społecznej. Co istotne, z czasem następowały także widoczne zmiany w zakresie pozycjonowania poszczególnych dziedzin będących jej częściami składowymi, wynikające zarówno ze wskazanych wyżej uwarunkowań, jak i ze stawianych z upływem czasu nowych bądź na nowo definiowanych celów.

\section{BUDOWA FUNDAMENTÓW}

W czasach Rady Regencyjnej polityka społeczna pozostawała jedną z dziedzin nieprzekazanych polskiej administracji, mimo to w ówczesnym Ministerstwie Zdrowia Publicznego, Opieki Społecznej i Ochrony Pracy prowadzone były zaawansowane prace nad własnymi rozwiązaniami w praktycznie wszystkich sferach 
oddziaływania państwa na kwestie społeczne. Były one szczególnie istotne w kontekście niezwykle zagmatwanego stanu prawnego i organizacyjnego panującego w poszczególnych zaborach. Dość powiedzieć, że w samych tylko ubezpieczeniach, uznawanych w tym czasie za najważniejszą obok ochrony pracy dziedzinę polityki społecznej, obowiązywały skrajnie różne rozwiązania - od w pełni nowoczesnych niemieckich urządzeń ubezpieczeniowych po niemal całkowity brak tego typu instytucji w obejmującym największą część ziem polskich zaborze rosyjskim. Znaczące odrębności obecne były również w pozostałych dziedzinach aktywności władz publicznych na polu społecznym, wskutek czego zadaniem podstawowym postawionym przed kierującymi polityką społeczną powstającego państwa stała się unifikacja obowiązujących przepisów ${ }^{1}$.

Odbywać się ona miała z wykorzystaniem najbardziej nowoczesnych rozwiązań, co $z$ jednej strony było zamierzeniem wartym podkreślenia i całkowicie uzasadnionym, z drugiej musiało oznaczać konieczność trudnego z wielu względów poszerzania zakresu świadczeń, ochrony i wsparcia na tych terenach, gdzie wcześniej ich poziom był niższy od uznawanego za docelowy. Promodernizacyjny ryt polskiej polityki społecznej był w tym pierwszym okresie wyraźnie widoczny praktycznie we wszystkich jej aspektach, a wzmacniać go musiały zarówno atmosfera społeczno-polityczna końca wojny, jak i fakt, iż gabinet Jędrzeja Moraczewskiego oparty był w dużej mierze na ugrupowaniach lewicowych, co w sposób determinujący przesądzało o kształcie przyjmowanych w pierwszych tygodniach wolności rozwiązań.

W istniejących okolicznościach pierwszy etap budowy własnej polityki społecznej przebiegał pod znakiem dużego optymizmu widocznego na każdym niemal jej polu i nie zawsze uwzględniającego obiektywnie istniejące bariery i uwarunkowania. Co istotne, przyniósł on szybkie wprowadzenie wielu nowoczesnych rozwiązań prawnych obejmujących, przynajmniej w teorii, całe terytorium państwa. Szczególnie widoczne były w tym względzie działania w zakresie leżącej u genezy samej polityki społecznej ochrony pracy. Już w listopadzie 1918 roku rząd Moraczewskiego wydał dekret wprowadzający ośmiogodzinny dzień pracy i obejmujący tak zwaną angielską sobotę, 46-godzinny tydzień pracy (przed wojną normą na ziemiach polskich był 9-10-godzinny dzień pracy, regulacje zaborcze pozwalały nawet na więcej)2 ${ }^{2}$.

Niewiele później, ale wciąż jeszcze w pierwszym roku niepodległości, pojawiły się przepisy regulujące funkcjonowanie Inspekcji Pracy, komisji rozjemczych w rolnictwie, związków zawodowych. Rok 1922 przyniósł niezwykle ważną ustawę o urlopach pracowniczych, a w lipcu 1924 roku została wydana ustawa o ochronie pracy młodocianych i kobiet, gwarantująca nie tylko wydanie spisu robót zabronionych tym kategoriom pracowników, ale wprowadzająca także zakaz pracy dzieci do lat 15, obowiązek kształcenia pracowników młodocianych (do 18. roku życia) oraz

${ }^{1}$ Szerzej na temat różnic dzielnicowych zob.: P. Grata, Procesy unifikacyjne w polskiej polityce społecznej w latach 1918-1939 [w:] Od kwestii robotniczej do nowoczesnej kwestii socjalnej. Studia z polskiej polityki społecznej XX i XXI wieku, t. I, red. P. Grata, Rzeszów 2013, s. 12-14.

${ }^{2}$ Z. Daszyńska-Golińska, Polityka spoteczna, Warszawa 1933, s. 247-248; H. Herkner, Kwestya społeczna w zachodniej Europie, Lwów 1905, s. 375. 
zakładania przez pracodawców żłobków dla dzieci robotnic (w zakładach zatrudniających ponad 100 kobiet) ${ }^{3}$.

W zasadzie trzeba zauważyć, że wstępny okres budowy polskiej polityki społecznej był zdecydowanie najbardziej owocny właśnie w sferze ochrony pracy, w innych działach było z tym już znacznie gorzej. Za symptomatyczne można uznać zwłaszcza doświadczenia w zakresie ubezpieczeń społecznych. Deficyt w tej mierze na terenach byłego zaboru rosyjskiego, a także brak ubezpieczenia emerytalnego dla robotników w dawnej Galicji stanowiły istotne zobowiązanie dla władz polskich. Stosunkowo szybko, bo już w roku 1919, powstał pierwszy projekt ustawy mającej zagwarantować dostęp do podstawowych form asekuracji we wszystkich dzielnicach państwa. Okazało się jednak, że przyjęcie tego typu rozwiązań całościowych nie będzie łatwe, co oznaczało konieczność budowy systemu za pomocą kolejnych działań cząstkowych ${ }^{4}$.

Pierwszym z nich stał się dekret, a następnie ustawa o ubezpieczeniu od choroby i macierzyństwa wprowadzająca na terytorium całego kraju rozwiązania wzorowane na niemieckich. Implementacja wprowadzanych przepisów musiała zostać rozłożona w czasie, jednak ustawa stała się w kolejnych latach podstawą budowy obejmującego całe państwo systemu lecznictwa ubezpieczeniowego. Krokiem kolejnym była unifikacja w 1923 roku przepisów emerytalnych dla pracowników państwowych i zawodowych wojskowych, w styczniu 1924 roku zaś na teren dawnego zaboru rosyjskiego rozciągnięto austriackie przepisy o ubezpieczeniu wypadkowym robotników. Domknięciem działań na tym polu stała się przyjęta w czerwcu 1924 roku ustawa o zabezpieczeniu na wypadek bezrobocia, stawiająca Polskę w gronie nielicznych państw oferujących takie ubezpieczenie ${ }^{5}$.

Pozornie udało się również w pierwszych latach niepodległości stworzyć podwaliny własnych systemów ochrony zdrowia oraz opieki społecznej, co miały gwarantować zasadnicza ustawa sanitarna z roku 1919 i aż o cztery lata późniejsza, przyjęta po trudnych sejmowych debatach dopiero w sierpniu 1923 roku, ustawa o opiece społecznej. Oba akty prawne miały jednak ramowy charakter, co czyniło je zaledwie zapowiedzią przyszłych regulacji szczegółowych. Oba też przekazywały zadania w zakresie opieki społecznej oraz niezwiązanej z ubezpieczeniami społecznymi ochrony zdrowia władzom samorządowym, co samo w sobie było rozwiązaniem słusznym, jednak w sytuacji gdy za zadaniami nie szły odpowiednie środki finansowe, skutkowało niskim poziomem zaspokojenia potrzeb w obu dziedzinach aktywności społecznej władz. Potwierdzeniem niewielkiego znaczenia praktycznego ustawy o opiece społecznej stała się ustawa z 1924 roku zawieszająca jej wejście w życie w byłym zaborze pruskim, gdzie nadal miały obowiązywać sprawdzone i znacznie bardziej konkretne przepisy niemieckie ${ }^{6}$.

${ }^{3}$ Dz. U. z 1922, nr 40, poz. 334; 1924, nr 65, poz. 636; Z. Da s zyń ska-Golińs k a, op. cit., s. 262.

${ }^{4} \mathrm{~K}$. Chylak, Ubezpieczenia społeczne i zaopatrzenia społeczne w II Rzeczypospolitej, Warszawa 2017, s. 97-115.

${ }^{5}$ Dz. Praw z 1919, nr 9, poz. 122; Dz. U. z 1920, nr 44, poz. 272; 1924, nr 6, poz. 46; nr 16, poz. 148; nr 67, poz. 650; K. Chylak, op. cit., s. 115-136.

${ }^{6}$ Dz. U. z 1919, nr 63, poz. 371; 1923, nr 92, poz. 726; 1924, nr 73, poz. 716; P. Grata, Polityka społeczna Drugiej Rzeczypospolitej. Uwarunkowania - instytucje - działania, Rzeszów 2013, s. 33-36. 
Kilkakrotnie wspominany wyżej rok 1924, związany z reformą skarbowo-walutową Władysława Grabskiego, stanowi wyraźną cezurę zamykającą pierwszy okres kształtowania własnej polityki społecznej. Duży wpływ na to miały stanowiące oś reformy oszczędności budżetowe. Jedną z ich ofiar stało się istniejące od października 1918 roku Ministerstwo Zdrowia Publicznego, które z początkiem roku 1924 zostało zniesione, a jego zadania przekazane do Ministerstwa Spraw Wewnętrznych, co w sposób pośredni musiało dowodzić degradacji miejsca problematyki zdrowia publicznego w polityce państwa ${ }^{7}$.

Dominacja w pierwszym okresie niepodległości kwestii związanych z ochroną pracy znajdowała również odzwierciedlenie w warstwie koncepcyjnej. Pierwsi ministrowie pracy i opieki społecznej często poruszali właśnie te zagadnienia, wciąż uznawane za najważniejsze $\mathrm{z}$ punktu widzenia polityki społecznej. Uprawnienia robotnicze, podobnie jak dążenie do objęcia ich ochroną ubezpieczeniową, pozostawały priorytetem kolejnych gabinetów, a tempo wprowadzania zapowiadanych rozwiązań miało zależeć od możliwości ekonomicznych państwa. Co interesujące, optymizm i wiara w dalszy rozwój instytucji ubezpieczeń społecznych jeszcze w roku 1920 nakazywały urzędnikom Ministerstwa Pracy i Opieki Społecznej zapisanie w uzasadnieniu do projektu ustawy o opiece społecznej przekonania o rychłym zmniejszaniu znaczenia działań opiekuńczych, które miały być zastępowane właśnie przez instytucje powszechnych i przymusowych ubezpieczeń społecznych ${ }^{8}$.

\section{POD SZTANDARAMI REALIZMU}

Wielki optymizm pierwszych miesięcy niepodległości musiał jednak ustąpić realizmowi i tak należałoby zdefiniować kolejny okres w procesie budowy polskiej polityki społecznej. Okres, co istotne, upływający pod znakiem dobrej koniunktury, ale także umacniania władzy sanacji, niechętnej w tym czasie eksperymentowaniu w sferze gospodarczej i społecznej. Tendencja ta widoczna stała się zarówno w warstwie koncepcyjnej, jak i praktycznej, nastawionej raczej na dopełnianie istniejącego systemu, często realizowane w drodze rozporządzeń prezydenckich. Bardzo wyraźnie podnoszone były w tym okresie uwarunkowania ekonomiczne polityki społecznej, co w kolejnych latach stanie się już niepodlegającą dyskusji normą, a także uzasadnieniem stabilnie niskich nakładów budżetu na tę część aktywności państwa9

$\mathrm{Z}$ drugiej strony warto docenić wysiłek włożony w tym czasie $\mathrm{w}$ dookreślenie budowanego od pierwszych miesięcy niepodległości systemu. Jego efekty widoczne

7 Ibidem, s. 47-48.

${ }^{8}$ P. Grata, Założenia i priorytety polskiej polityki społecznej w latach 1918-1939, „Polityka i Społeczeństwo" 2012, nr 10, s. 33-35.

${ }^{9} \mathrm{Na}$ temat skarbowych uwarunkowań polityki społecznej zob.: P. Grata, At the Origins of Welfare State? Social Expenses in the Budgetary Policy in the Second Polish Republic, „Studia Historiae Oeconomicae" 2017, t. 35, s. 7-26. 
były praktycznie we wszystkich dziedzinach polityki społecznej, choć od razu trzeba zastrzec, że nie wszystkie zamierzenia w tym korzystnym z punktu widzenia uwarunkowań ekonomicznych okresie udało się zrealizować. Mimo tego przywołać należy w tym miejscu istotne uzupełnienia wprowadzone drogą rozporządzeń prezydenckich w zakresie ochrony pracy, do których zaliczyć trzeba akt trwale regulujący funkcjonowanie Inspekcji Pracy z 14 lipca 1927 roku, rozporządzenie o zapobieganiu i zwalczaniu chorób zawodowych z 22 sierpnia 1927 roku, uregulowanie przepisów o umowie o pracę robotników oraz pracowników umysłowych (dwa akty z 16 marca 1928 r.), przepisy w zakresie bezpieczeństwa i higieny pracy (16 marca 1928 r.) czy też rozporządzenie z 22 marca 1928 roku w sprawie sądownictwa pracy będące podstawą budowy obejmującego całe państwo systemu instytucji stojących na straży przestrzegania ustawodawstwa ochronnego ${ }^{10}$.

Ważne zmiany prawne i organizacyjne pojawiły się w II połowie lat dwudziestych również w pozostałych działach polityki społecznej. 24 listopada 1927 roku ukazało się rozporządzenie Prezydenta o ubezpieczeniu społecznym pracowników umysłowych zapewniające pełną zunifikowaną w całym kraju ochronę od podstawowych ryzyk życiowych przedstawicielom tej grupy zawodowej. W sferze działalności opiekuńczej znaczenie szczególne miało rozporządzenie z 6 marca 1928 roku o opiekunach społecznych i komisjach opieki społecznej, określające podstawy instytucjonalne realizacji zadań samorządów w tym obszarze. W ochronie zdrowia znaczenie systemowe miały mieć przepisy o zakładach leczniczych wydane 22 marca 1928 roku, chociaż z założenia nie obejmowały one obszarów byłej Galicji11 .

Mimo wskazanych wyżej regulacji znacząco dopełniających ramy instytucjonalne polskiej polityki społecznej wciąż nie udało się w omawianym okresie doprowadzić do końca prac nad tak zwaną ustawą scaleniową. Miała ona zunifikować system ubezpieczeń społecznych, a także poszerzyć go o ubezpieczenie emerytalne robotników, nadal nieobecne na większości terytorium państwa. Odpowiedni projekt zakładający powszechne i obowiązkowe ubezpieczenie robotników na wypadek choroby, macierzyństwa, wypadków, starości, inwalidztwa i śmierci trafił nawet do parlamentu wiosną 1929 roku, jednak jeszcze w tym samym roku został zeń wycofany, a to oznaczało, że system ubezpieczeń społecznych pozostawał przez kolejne lata bardzo ułomny. Nie udało się również w tym okresie rozszerzyć zakresu podmiotowego ubezpieczenia od bezrobocia, od początku obejmującego jedynie pracujących w zakładach zatrudniających powyżej pięciu pracowników. Przeforsowana w Sejmie ustawa z 25 marca 1929 roku zapowiadała zniesienie tego ograniczenia, jednak rychły początek kryzysu i pogorszenie sytuacji finansowej Funduszu Bezrobocia odsunęły w bliżej nieokreśloną przyszłość realizację tego zamierzenia ${ }^{12}$.

${ }^{10}$ Dz.U. z 1927, nr 67, poz. 590; nr 78, poz. 676; z 1928, nr 35, poz. 323, 324, 325; nr 37, poz. 350; Materiały odnoszace się do działalności Rzadu w czasie od 15 maja 1926 do 31 grudnia 1927. Sprawozdania ministerstw, Warszawa 1928, s. 566-570.

${ }^{11}$ Dz. U. z 1927, nr 106, poz. 911; z 1928, nr 29, poz. 267; nr 38, poz. 382.

12 Dz. U. z 1930, nr 3, poz. 18; Z. Landau, Podstawowe kierunki rozwoju ubezpieczeń społecznych [w:] Rozwój ubezpieczeń społecznych w Polsce, Warszawa 1990, s. 36-39; L. Sk arżyński, Projekt ustawy o ubezpieczeniu społecznem, „Przegląd Ubezpieczeń Społecznych” 1929, z. 6, s. 115-121. 


\section{PRZEWARTOŚCIOWANIE}

Niewykorzystanie szansy na dokończenie budowy systemu polityki społecznej w okresie dobrej koniunktury II połowy lat dwudziestych oznaczało, że w największy w dziejach kryzys wchodziła ona w postaci niepełnej, pozbawiona kilku ważnych elementów, wśród których najbardziej dotkliwy pozostawał deficyt ochrony ubezpieczeniowej robotników. Tymczasem załamanie koniunktury i trwałość recesji postawiły przed zawiadującymi polską polityką społeczną wiele nowych, nieobecnych wcześniej wyzwań, które z czasem musiały przynieść przewartościowanie obowiązujących priorytetów i przejście na bardzo reaktywny charakter działań. Wyraźnie widoczne stało się również trwałe odejście od entuzjazmu pierwszych lat niepodległości i zastępowanie go bezwzględnym, wynikającym z uwarunkowań ekonomicznych pragmatyzmem.

W nowych warunkach celem podejmowanych w ramach polityki społecznej działań było przede wszystkim minimalizowanie negatywnych skutków kryzysu. W związku z tym, paradoksalnie, to właśnie na początku lat trzydziestych wydatki budżetowe resortu pracy i opieki społecznej okazały się najwyższe w całym okresie międzywojennym. Generowane przez lawinowy wzrost bezrobocia nakłady szły na zasiłki dla bezrobotnych, organizację robót publicznych, a także pomoc doraźną dla pozbawionych pracy. Wraz z pogarszaniem sytuacji budżetu ekspansja wydatków szybko uległa zahamowaniu (redukcja z blisko $154 \mathrm{mln}$ zł w roku 1931/32 do nieco ponad $100 \mathrm{mln}$ w kolejnych dwóch latach oraz $65 \mathrm{mln}$ zł w roku 1934/35), a oszczędności dotknąć miały wszystkich dziedzin polityki społecznej ${ }^{13}$.

W przypadku pomocy doraźnej dla bezrobotnych zasiłki pieniężne już w roku 1931 zostały zastąpione świadczeniami rzeczowymi, a źródłem wsparcia miała być przede wszystkim dobroczynność publiczna. W opiece społecznej zredukowano subwencje na utrzymywanie zakładów opiekuńczych, zwiększał się nacisk na formy opieki otwartej, w ramach której można było pomóc znacznie większej liczbie potrzebujących. Władze szeroko zaczęły propagować także instytucję rodziny zastępczej, nie tylko korzystną z punktu widzenia podopiecznych, ale przede wszystkim tańszą od opieki zakładowej. Zamiast rozszerzenia zakresu podmiotowego asekuracji ograniczono uprawnienia zasiłkowe objętych ubezpieczeniem od braku pracy bezrobotnych, w ubezpieczeniu chorobowym wprowadzono zaś niewielkie opłaty za wizyty u lekarza i otrzymywane leki, zmniejszono wysokość zasiłków chorobowych, a państwo przestało dopłacać do świadczeń dla położnic ${ }^{14}$.

Te ostatnie zmiany stały się skutkiem ubocznym wieloletniego odwlekania wprowadzenia zunifikowanego, obejmującego pełen pakiet instrumentów asekuracyjnych, systemu ubezpieczeń społecznych. Kolejny projekt ustawy scaleniowej trafił bowiem do parlamentu wiosną 1932 roku, a więc w okresie największego załamania kryzysowego, przyjęty zaś został rok później, gdy kontekst ekonomiczny wcale się

${ }_{13}$ P. Grata, At the Origins..., s. 13.

${ }^{14}$ Polityka społeczna państwa polskiego 1918-1935, Warszawa 1935, s. 166-167, 248-251. 
nie poprawił. W takich okolicznościach wprowadzenie nowego obciążenia na życie gospodarcze, jakim bezsprzecznie stać się miały składki na ubezpieczenie rentowe robotników, musiało zostać złagodzone pewnym ograniczeniem kosztów w innych elementach systemu. Ofiarą stały się zatem wspomniane świadczenia chorobowe, jak też ubezpieczenie od choroby robotników rolnych, którego w ustawie scaleniowej zabrakło (ochronę od starości miała ustanowić odrębna ustawa, jednak jej projekt nigdy nie został przez parlament przyjęty). W ten sposób ważna i wprowadzająca wreszcie po piętnastu latach ubezpieczenie emerytalne robotników ustawa została okupiona ograniczeniem części wcześniej dostępnych uprawnień asekuracyjnych, a kontekst kryzysu, przekładając się na niski poziom składek, zapowiadał niewielką wysokość przyszłych świadczeń ${ }^{15}$.

Co więcej, wraz z uchwaleniem ustawy o ubezpieczeniu społecznym władze przeforsowały również w parlamencie niekorzystne dla pracujących, a opłacalne dla przedsiębiorców zmiany w ustawodawstwie pracy. Dwiema ustawami z 22 marca 1933 roku, mimo protestów ze strony opozycji i związanych z nią środowisk robotniczych, zmieniono przepisy dotyczące czasu pracy (zniesienie angielskiej soboty i wprowadzenie 48-godzinnego tygodnia zatrudnienia) oraz urlopów (sposób naliczania obejmujący dni wolne od pracy). W ten sposób w drugiej dekadzie niepodległości nastąpił regres w zbudowanym kilkanaście lat wcześniej systemie ustawodawstwa pracy, a kierunek zachodzącej w tym względzie ewolucji był zdecydowanie niekorzystny dla pracobiorców, co w sposób widoczny dowodziło zmiany priorytetów polskiej polityki społecznej ${ }^{16}$.

Kwestią zdecydowanie najważniejszą stał się bowiem w tym okresie problem bezrobocia, które nie tylko szybko się zwiększało, ale również stanowiło zjawisko niemalże niepoliczalne. Wskazywały na to zarówno wyniki spisu powszechnego z 1931 roku, jak i szacunki dotyczące liczonych w milionach ,ludzi zbędnych” rozmiarów bezrobocia ukrytego na wsi. Polityka względem tego zjawiska oparta była w okresie kryzysu na dwutorowości działań. $Z$ jednej strony władze dążyły do zahamowania wzrostu bezrobocia, co jednak w warunkach utrzymującej się depresji było trudne do osiągnięcia. Z drugiej strony wyraźny nacisk położony na walkę z bezrobociem przyniósł utworzenie w 1933 roku Funduszu Pracy, czyli instytucji powołanej przede wszystkim do organizowania uznanych za najpewniejszy sposób przeciwdziałania brakowi pracy robót publicznych i wyposażonej, co istotne, we własne źródła dochodów. Były one na tyle pokaźne, że znacząco przekraczały budżet „socjalny” rządu, co pozwalało oczekiwać realnych efektów oddziaływania na przynajmniej miejską część rynku pracy ${ }^{17}$.

Ważnym i dającym nadzieję na nowe podejście do kolejnej niezwykle zaniedbanej sfery życia społecznego wydarzeniem stała się przeprowadzona w roku 1932 unifikacja w zakresie struktur zarządzających polską polityką społeczną. Po wielu

15 Dz.U. z 1933, nr 51, poz. 396; K. Chylak, op. cit., s. 379-394.

16 Dz. U. z 1933, nr 27, poz. 227, 228; Polityka społeczna ..., s. 116-118.

17 Dz. U. z 1933, nr 22, poz. 163; Mały Rocznik Statystyczny 1939 (dalej: MRS), s. 259; Sprawozdanie z działalności Funduszu Pracy za okres od 1 kwietnia 1934 r. do 31 marca 1935 r., Warszawa 1936, s. $3-10 \mathrm{~b}$ 
latach zgłaszanych w tym względzie postulatów z dniem 1 lipca tego roku nastąpiło włączenie w zakres kompetencji dotychczasowego resortu pracy i opieki społecznej podporządkowanych wcześniej MSW spraw ochrony zdrowia. Równocześnie resort przyjął nazwę Ministerstwa Opieki Społecznej, co miało wskazywać na znaczące poszerzenie zakresu jego zainteresowania i stanowić pewnego rodzaju symboliczne odejście od raczej wąsko dotychczas pojmowanego, wiązanego głównie z miejskimi środowiskami pracowniczymi, rozumienia polityki społecznej. Przede wszystkim był to jednak, zdaniem zawiadujących resortem, wielki krok w sferze tak zaniedbywanej wcześniej publicznej służby zdrowia ${ }^{18}$.

\section{KU LEPSZEJ PRZYSZŁOŚCI?}

Szansę na ziszczenie chociaż części oczekiwań związanych z unifikacją zarządu sprawami społecznymi przez Ministerstwo Opieki Społecznej przynieść miała poprawa koniunktury w gospodarce widoczna w połowie lat trzydziestych. Wraz z nią następowała dalsza ewolucja koncepcyjna polskiej polityki społecznej, a coraz większego znaczenia nabierały zagadnienia wprost wypływające z rodzimej specyfiki oraz dobrze już zidentyfikowanych po ponad piętnastu latach niepodległości podstawowych kwestii socjalnych. Obok uznawanego za największą wadę życia społecznego strukturalnego bezrobocia zaliczano do nich wtedy wielkie niedostatki, dzisiaj zwane deprywacją, w zakresie realizacji potrzeb zdrowotnych i opiekuńczych na terenach wiejskich. Skutkiem tego stały się zarówno liczne spotkania i konferencje poświęcone obu problemom, jak i próby działań podejmowanych na rzecz rozwoju infrastruktury ochrony zdrowia czy „pójścia z opieką na wieś” (w tle nowych tendencji w polityce społecznej wyraźnie widoczne były projekty modernizacyjne Eugeniusza Kwiatkowskiego oraz coraz większe zrozumienie istnienia iunctim między stanem zdrowia ludności a możliwościami obronnymi państwa) ${ }^{19}$.

Praktyka nadal jednak pozostawiała wiele do życzenia, a podstawową tego przyczyną był fakt, iż w polityce społecznej wciąż obowiązująca pozostawała sformułowana przez ministra opieki społecznej Władysława Jaszczołta w Sejmie w lutym 1936 roku zasada „na co nas stać i co jest w naszych warunkach rzeczą najpilniejszą" ${ }^{20}$. Determinowała ona w warunkach niezmiennie niskich nakładów budżetowych skromny zakres realnych możliwości oddziaływania na bardzo dobrze zdiagnozowaną, ale pełną wad rzeczywistość. Mimo to warto podkreślić nie tylko werbalne wsparcie resortu opieki społecznej dla rozbudowy sieci ośrodków zdrowia,

18 P. Grata, Polityka..., s. 42-43.

19 Zob. np. J. Danielski, Pomoc lecznicza na wsi, „Praca i Opieka Społeczna” (cyt. PiOS) 1938, nr 4, s. 434-442; B. Nakoni ecznikow-Klukowski, Przegląd najbardziej aktualnych zagadnień z zakresu polityki opiekuńczej, ibidem, nr 1, s. 22-24.

${ }^{20}$ Sprawozdania stenograficzne z posiedzeń Sejmu (cyt. SS), Okres IV, pos. 15 z 22 II 1936, łamy $12-13$. 
które stać się miały podstawą objęcia lecznictwem publicznym nieubezpieczonych mas ludności, ale też szybki rozwój akcji kolonijnej, pojawienie się i mozolną rozbudowę wiejskich placówek opieki otwartej nad dziećmi, a także postępy w zakresie zakładania żłobków przyfabrycznych ${ }^{21}$.

Wciąż umacniała się w II połowie lat trzydziestych pozycja polityki zatrudnienia, a katalog wykorzystywanych w jej ramach instrumentów aktywizacji osób bezrobotnych mógł budzić uznanie. Obok rozbudowanych na niespotykaną dotychczas skalę robót publicznych obejmował on między innymi połączone ze szkoleniem zawodowym wspieranie zatrudnienia bezrobotnej młodzieży (również wiejskiej), subwencjonowane zatrudnienie bezrobotnych pracowników umysłowych, poradnictwo i szkolenie zawodowe, dofinansowywanie tworzenia drobnych warsztatów pracy czy celowe przesiedlanie bezrobotnych. Fundusz Pracy podjął się również finansowania, w ramach Towarzystwa Osiedli Robotniczych, budowy tanich mieszkań robotniczych na wynajem, co po raz kolejny wskazywać mogło na dokonujący się przełom koncepcyjny w polskiej polityce społecznej. Mimo wszystkich pozytywnych aspektów polityki zatrudnienia należy zaznaczyć, iż była ona w istniejących uwarunkowaniach strukturalnych z zasady skazana na niepowodzenie, a najlepszym tego potwierdzeniem stał się systematyczny wzrost liczby zarejestrowanych bezrobotnych postępujący wraz z poprawą koniunktury i zwiększaniem zatrudnienia w sektorach pozarolniczych w II połowie lat trzydziestych ${ }^{22}$.

Dosyć podobne były wprawdzie perspektywy w zakresie pozostałych dziedzin polityki społecznej, jednak warto dostrzec, że stawiane wtedy dalekosiężne cele znajdowały widoczne odzwierciedlenie $\mathrm{w}$ procedowanych, a nawet przyjmowanych przez parlament projektach ustawodawczych. Dowodem na tak postawioną tezę były regulacje dotyczące dalszej unifikacji systemu ubezpieczeń społecznych, wprowadzenia sądownictwa ubezpieczeniowego, wykonywania zawodu lekarza (z nakazem odbywania dwuletniej praktyki na terenach wiejskich lub w małych miasteczkach), a przede wszystkim ustawa o publicznej służbie zdrowia z czerwca 1939 roku, określająca konkretne zasady budowy takiego systemu w Rzeczypospolitej. Mimo że wskutek wybuchu wojny trudno o weryfikację potencjalnych efektów, jednak warto o nich pamiętać w kontekście wciąż trwającego do lata 1939 roku procesu budowy polskiej polityki społecznej oraz zachodzącej w jej ramach ewolucji. Z drugiej strony zastrzec należy, że wciąż w sferze trwających już kilkanaście lat prac projektowych pozostawała na przykład ustawa o ochronie macierzyństwa, mająca stać się de facto punktem wyjścia do spójnej i wszechstronnej polityki rodzinnej (czynnik ekonomiczny pozostawał tutaj barierą nie do pokonania) ${ }^{23}$.

${ }^{21}$ Sprawozdanie z działalności Ministerstwa Opieki Społecznej w 1937/38 r., PiOS 1938, nr 4, s. 517-523, 535-536; I. Zawadowska, Ochrona macierzyństwa robotnicy w Polsce, „Statystyka Pracy" 1937, nr 4, s. 295-298.

22 MRS 1939, s. 267; Sprawozdanie z działalności Funduszu Pracy za okres od 1 kwietnia 1937 r. do 31 marca 1938 r., Warszawa 1938, passim.

${ }_{23}$ Dz. U. z 1938, nr 56, poz. 446; nr 57, poz. 449; nr 69, poz. 505; z 1939, nr 54, poz. 342; nr 71, poz. 476; P. Grata, Polityka..., s. 34-35. 
Mimo niepowodzeń warto dostrzec pewną dojrzałość koncepcyjną, jaką polska polityka społeczna w tym czasie osiągnęła. Obok tradycyjnych stawiano przed nią już wtedy cele znacznie szersze, silnie wpisane w dążenia modernizacyjne i nastawione w dużej mierze na profilaktykę, a nie tylko proste reagowanie na pojawiające się problemy. W lutym 1939 roku minister opieki społecznej Marian Zyndram-Kościałkowski mówił zatem w Sejmie nie tylko o podstawowych i wciąż kluczowych dziedzinach będących już wcześniej przedmiotem zainteresowania resortu, ale także o zapobieganiu wypadkom w zatrudnieniu, profilaktyce zdrowia pracowników, aktywnych formach przeciwdziałania bezrobociu oraz znaczeniu stanowiącego „najpilniejszą sprawę społeczną" zatrudnienia młodzieży. Wyraźnie zwracał uwagę na kwestie demograficzne rozpatrywane zarówno w kontekście uwidaczniającego się spowolnienia tempa przyrostu naturalnego, jak i konieczności podejmowania skutecznych działań ograniczających wciąż niezwykle wysoką śmiertelność niemowląt oraz gwarantujących odpowiednią opiekę (wszechstronną) nad matką i dzieckiem. Za znamienną w kontekście zachodzących procesów uznać należy sugestię ministra, iż jego resort winien się nazywać Ministerstwem Spraw Społecznych ${ }^{24}$.

Dokonujące się w II połowie lat trzydziestych przemiany koncepcyjne w polskiej polityce społecznej można było dostrzec w wielu jej aspektach szczegółowych. Ze względu na wciąż trwałe i wynikające $\mathrm{z}$ decyzji politycznych ograniczenia finansowe elementy nowoczesności pozostawały raczej enklawami i czymś, co moglibyśmy dzisiaj nazwać „programami pilotażowymi”, warto jednak zwrócić na nie uwagę, gdyż wydaje się, że to one miały wskazywać dalszy kierunek rozwoju wciąż tworzonej własnej polityki społecznej. Można by tutaj wymienić chociażby wspomniany wyżej nacisk na rozwój budownictwa mieszkaniowego czy też zwiększanie roli instytucji rodziny zastępczej w opiece nad dziećmi opuszczonymi, ale także ideę zorganizowanych wczasów pracowniczych, która uzyskała tuż przed wybuchem wojny silne wsparcie ze strony państwa ${ }^{25}$.

\section{PODSUMOWANIE}

Dwadzieścia lat niepodległości okazało się okresem zbyt krótkim na dokończenie procesu budowy własnego i spójnego systemu polityki społecznej. Trudno jednak stawiać z tego powodu władzom II Rzeczypospolitej większe zarzuty. Skomplikowany

${ }^{24}$ SS Sejm, Okres V, pos. 12 z 17 II 1939, łamy 70-79; oficjalnie podawany, zdaniem znawców tematu zaniżony, wskaźnik śmiertelności niemowląt jeszcze w roku 1938 wynosił 140 zgonów na 1000 urodzeń żywych, czyli był niewiele tylko niższy niż dekadę wcześniej, podczas gdy nawet w gorzej rozwiniętych państwach Europy Zachodniej śmiertelność kształtowała się wtedy na poziomie poniżej 100 zgonów na 1000 urodzeń (wartości podobne do polskich utrzymywały się na Bałkanach i w części państw Europy Wschodniej), zob. P. Grat a, Polityka..., s. 287-288.

${ }^{25}$ Warto zauważyć, że do każdej z tych kwestii dużo wagi przykładali rządzący Polską po wojnie komuniści, zob. P. Grata, Czas przełomu. Polska polityka społeczna w latach 1944-1950, Rzeszów 2018, passim. 
bilans otwarcia, konieczność usuwania różnic dzielnicowych, niekorzystna struktura gospodarcza i społeczna państwa, a wreszcie permanentny brak środków uniemożliwiały wręcz stworzenie adekwatnego do potrzeb systemu. Znajdował się on zatem wciąż w fazie budowy, stawał się coraz bardziej pełny, ale równocześnie skrajnie niedofinansowany, czego potwierdzeniem był wynikający z nieusuwalnych barier strukturalnych skromny zakres podmiotowy jego beneficjentów. Przełamanie tego stanu było niemożliwe w ciągu tak krótkiego czasu, choć skala braków i niedostatków była w pełni uświadomiona, czego potwierdzeniem były zarówno wskazane wyżej zmiany w latach trzydziestych, jak i późniejsze prace koncepcyjne prowadzone w okresie okupacji.

Z nowymi koncepcjami i zmianą priorytetów zachodzącą w latach trzydziestych ściśle wiązała się widoczna ewolucja polityki społecznej państwa polskiego. Zjawisko to wynikało z coraz lepszego diagnozowania części słabo wcześniej dostrzeganych potrzeb społecznych, jak również było naturalną konsekwencją nieodłącznie związanego z polityką społeczną ewolucyjnego właśnie charakteru kwestii socjalnej. Wskutek tych czynników, a także ujawniających się kolejnych zadań polska polityka społeczna stawała się z czasem coraz bardziej dojrzałą, choć nadal nie w pełni ukształtowaną, sferą aktywności państwa, czego potwierdzeniem były zarówno stawiane przed nią w końcu lat trzydziestych nowe cele, jak i podejmowane wtedy działania regulacyjne i praktyczne.

Co równie istotne, zbudowane do 1939 roku podstawy prawne, instytucjonalne i organizacyjne stały się po zakończeniu wojny punktem wyjścia odbudowy, a później przebudowy systemu polskiej polityki społecznej. I mimo że z czasem został on wskutek wkroczenia komunistów na drogę stalinizmu skrajnie wypaczony, w najtrudniejszych pierwszych latach po wyzwoleniu mogli oni z niego czerpać, a warunki startu były dzięki temu znacznie lepsze niż te, z którymi przyszło się zmierzyć twórcom polityki społecznej niepodległego państwa w okresie międzywojennym.

\section{BIBLIOGRAFIA}

Chylak K., Ubezpieczenia społeczne i zaopatrzenia społeczne w II Rzeczypospolitej, Warszawa 2017.

D anielsk i J., Pomoc lecznicza na wsi, „Praca i Opieka Społeczna” 1938, nr 4.

Das zyńska-Golińska Z., Polityka społeczna, Warszawa 1933.

„Dziennik Praw Państwa Polskiego” 1919.

„Dziennik Ustaw Rzeczypospolitej Polskiej” 1919-1939.

Grata P., At the Origins of welfare state? Social Expenses in the Budgetary Policy in the Second Polish Republic, „Studia Historiae Oeconomicae” 2017, t. 35.

Grata P., Czas przełomu. Polska polityka społeczna w latach 1944-1950, Rzeszów 2018.

Grata P., Polityka społeczna Drugiej Rzeczypospolitej. Uwarunkowania-instytucje - dziatania, Rzeszów 2013.

Grata P., Procesy unifikacyjne w polskiej polityce społecznej w latach 1918-1939 [w:] Od kwestii robotniczej do nowoczesnej kwestii socjalnej. Studia z polskiej polityki spolecznej XX $i$ XXI wieku, t. I, red. P. Grat a, Rzeszów 2013. 
Grata P., Założenia i priorytety polskiej polityki społecznej w latach 1918-1939, „Polityka i Społeczeństwo" 2012, nr 10.

Herkner H., Kwestya społeczna w zachodniej Europie, Lwów 1905.

Landau Z., Podstawowe kierunki rozwoju ubezpieczeń społecznych [w:] Rozwój ubezpieczeń spolecznych w Polsce, Warszawa 1990.

„Mały Rocznik Statystyczny” 1939.

Materiaty odnoszace się do działalności Rzadu w czasie od 15 maja 1926 do 31 grudnia 1927. Sprawozdania ministerstw, Warszawa 1928.

Nakoni e znikow-Klukow s k i B., Przeglad najbardziej aktualnych zagadnień z zakresu polityki opiekuńczej, „Praca i Opieka Społeczna” 1938, nr 1.

Polityka społeczna państwa polskiego 1918-1935, Warszawa 1935.

S karżyń s ki L., Projekt ustawy o ubezpieczeniu społecznem, „Przegląd Ubezpieczeń Społecznych"1929, z. 6.

Sprawozdania stenograficzne z posiedzeń Sejmu, Okres IV, Okres V.

Sprawozdanie z dziatalności Funduszu Pracy za okres od 1 kwietnia 1934 r. do 31 marca $1935 r$., Warszawa 1936.

Sprawozdanie z działalności Funduszu Pracy za okres od 1 kwietnia 1937 r. do 31 marca 1938 r., Warszawa 1938.

Sprawozdanie z działalności Ministerstwa Opieki Społecznej w 1937/38 r., „Praca i Opieka Społeczna" 1938, nr 4.

Zaw adowska I., Ochrona macierzyństwa robotnicy w Polsce, „Statystyka Pracy” 1937, nr 4. 